\title{
Microbiological Evaluation and Antibiotic Susceptibility Pattern of Bacterial Isolates Associated with Some Contaminated Edible Fruits and Vegetables
}

Mallikarjun Gundappa', C. Prabhurajeshwar ${ }^{2}$, Sarfaraz Ahmed ${ }^{3}$, H.M. Navya' ${ }^{2}$ M. Vijayasarathy ${ }^{4}$, Shanmugam Velayuthaprabhu ${ }^{1}$

10.18805/IJARe.A-5681

\begin{abstract}
Background: The present study was undertaken to study the percentage of pathogenic bacteria present in different fruit and vegetable samples available in the market in and around Kalaburagi, Karnataka, South India.

Methods: A total of 940 different samples were collected from Kalaburagi, out of which $390(23.84 \%)$ were fruits and 550 (35.27\%) were vegetables. The pathogenic bacteria were isolated, by enrichment culture method using peptone water. The bacterial isolates were identified by convention microbial identification procedures.

Result: Antibiotic resistant testing by disc diffusion method performed for E.coli, Salmonella and Shigella. Among the pathogens, E. coli $(86.50 \%)$ of the isolates were resistant to Nalidixic acid while Imipenem and Trimethoprim-Sulfamethoxazole has the lowest resistance $(19.84 \%)$, Salmonella $(86.66 \%)$ isolates were resistant to Ciprofloxacin while Norfloxacin has the lowest resistance $(4.76 \%)$ and Shigella (80.35\%) isolates were resistant to Vancomycin while Amoxicillin has the lowest resistant (3.57\%). Multiple drug resistance (MDR) was seen in E. coli at (38.88\%), Salmonella at (26.66\%) and Shigella at (10.71\%) accordingly. The study therefore shown that E.coli, Salmonella and Shigella occur in Fruits and vegetables which collected from market place in Kalaburagi, Karnataka India, As per the results, adequate precaution should be taken while handles these fruits and vegetables. The antimicrobial resistance pattern shown by the isolates is an indication that adequate measurement needs to be taken to regulate the drug use in both humans and animals in order to minimize the risk of increasing antimicrobial resistance.
\end{abstract}

Key words: Antibiogram fruits and vegetables, E.coli, Salmonella, Shigella.

\section{INTRODUCTION}

Fresh fruits and vegetables provide mankind with an abundance of benefits. They give the necessary vitamins, fats, minerals and oil to the body in the right proportion for human growth and development. These play an important role in health and have the ability to prevent many diseases such as heart disease, cancers and diabetes (Liu, 2003; Pandey and Rizvi 2009). Fruits and vegetables play a major role worldwide and have more attention in Kalaburagi of south India as a major diet probably due to its health benefits, low cost availability and active promotion of fresh Fruits and vegetables as a part of a healthy diet (Mallikarjun and Gaddad, 2016; Mallikarjun and Gaddad, 2016).

Over the years, there has been increase in the need to identify and isolate the microorganisms associated with the spoilage as a way of finding a means of controlling it (Akinyele and Akinkunmi, 2012). Fresh fruits and vegetables are essential components of the human diet and there is considerable evidence of the health and nutritional benefits associated with this consumption. Despite the benefits derived from fruits and vegetables, they are major sources of food borne diseases (Robinson et al., 2000).

Recent improvement of the standard of life in India is associated with diversification of food needs including availability of fresh food producedeverywhere throughoutthe year. All these require proper transport and storage facility.
'Department of Biotechnology, Bharathiar University, Coimbatore641 046, Tamil Nadu, India.

${ }^{2}$ Department of Biotechnology, Davangere University, Davangere577002 Karnataka, India.

${ }^{3}$ Department of Microbiology, Gulbarga University, Kalaburagi-585 106, Karnataka, India.

${ }^{4}$ Department of Microbial Biotechnology, Bharathiar University, Coimbatore-641 046, Tamil Nadu India.

Corresponding Author: Shanmugam Velayuthaprabhu, Department of Biotechnology, Bharathiar University, Coimbatore641 046, Tamil Nadu, India. Email: velayuthaprabhu@buc.edu.in

How to cite this article: Gundappa, M., Prabhurajeshwar, C., Ahmed, S., Navya, H.M., Vijayasarathy, M. and Velayuthaprabhu, S. (2021). Microbiological Evaluation and Antibiotic Susceptibility Pattern of Bacterial Isolates Associated with Some Contaminated Edible Fruits and Vegetables. Indian Journal of Agricultural Research. DOI: 10.18805/IJARe.A-5681.

Submitted: 12-09-2020 Accepted: 05-04-2021 Online: 30-04-2021

India is the second largest producer of fruits and vegetables in the world and accounts for about $15 \%$ of the world's total production. Fruits and vegetables plays key role in growth and development of body and in prevention of many diseases due to high nutritive value. The majority of diseases associated with fresh fruits and vegetables are primarily those 
transmitted by the faecal-oral route and therefore, a result of contamination at some point in the process (De Rover, 1988).

Incidences of disease associated with bacteria have been attributed mainly to Escherichia coli, Salmonella, Listeria, Shigella, Bacillus, Aeromonas, Clostridium and Campylobacter (Beuchat, 1995). Fruits and vegetable samples examined in Kalaburagi were contaminated with Salmonella, shigella and E. coli (Mallikarjun and Gaddad, 2016). A Study conducted in India on salad vegetables, revealed the presence of $E$. coli, Enterobacteraerogenes, Pseudomonas spp., S. aureus, Salmonella spp. and Shigella spp., (Fain, 1996). Further, WHO reports that leafy green vegetables are of great concern in terms of microbiological hazards (WHO, 2008).

As seen above Salmonella and Shigella species have been associated with food borne diseases with significant morbidity and mortality rate in people of all ages. In the U.S. between 1995 and 1998, there were 9 outbreaks of food borne illnesses caused by Salmonella, E. coli 0157:H7 due to consumption of fresh vegetable sprouts (Martin et al., 2003). There have been an increasing number of outbreaks of food poisoning linked to the consumption of vegetables and fruit in Westernised countries. The number of reported outbreaks in the USA more than doubled from the period 1973-1987 to the period 1988-1991 (Tauxe et al., 1997). Recently, association between fresh vegetables and outbreaks of food borne infections has led to a greater concern about contamination of vegetables with a pathogenic bacterium like E. coli, Vibrio, Salmonella, Norovirus, Shigella, Listeria etc (Mahima et al., 2013).

These fruits and vegetables can also get contaminated with pathogenic microbes during harvesting, transportation, storage and retailers handling. These are the wide range sources of microbial contamination to different varieties of fruits and vegetables (Ray and Bhunia, 2007).

Moreover, the availability of potable water for proper washing of fruits and vegetables is also lacking in different areas. As a result of which dirty or contaminated water is used for washing, which could lead to further increasing the microbial load on these vegetables which some people buy and eat without further washing. Previous report revealed that Listeria monocytogenes and Salmonella spp. have been isolated from raw vegetables making them potential threat to consumers (Biniam and Moggessie 2010).

Most of the reported outbreaks of gastrointestinal disease linked to the fresh produce have been associated with bacterial contamination, particularly with members of the Enterobacteriaceaefamily (Hamilton et al., 2006). Occasional reports of multistate outbreaks of Salmonellosis in the United States associated with contaminated fresh fruits and vegetables have coincided with increased consumption of fresh produce in recent years due to changing consumer preferences, greater selections, wider distribution and yearround availability (Hedberg et al., 1994).
Excessive and misuse of antimicrobials to control pathogens in animals and crops led to antibiotic resistance and transfer to human through contaminated food. These are consistent with earlier reports which shown that antibiotic resistant bacteria also may be ingested with vegetables (Kilonzo et al., 2009). Vegetables such as corn, green onion and cabbage absorb antibiotics when grown in soil fertilized with livestock antibiotics contaminated manure (Kumar et al., 2005).

Microbiological studies from many developing countries carried out on street vended food articles. These studies have revealed that a high bacteria count on the edible fruits and vegetables. Salmonella species, S.aureus and members of the family, Enterobacteriaceae were common pathogens found in such food items (Bryan et al., 1997). Enteric pathogens such as E. coli and Salmonella are among the greatest concerns during food related outbreaks (Buck et al., 2003).

Food contamination with antibiotic resistant bacteria can be a major threat to public health, as the antibiotic resistance determinants can be transferred to other pathogenic bacteria potentially compromising the treatment of severe bacterial infections. The prevalence of antimicrobial resistance among food pathogens has increased during recent decades (Davis et al., 1999). Thus the present study was under taken for antibiotic susceptibility of pathogenic bacteria such as E.coli spp., Salmonella spp. and Shigella spp., from fruits and vegetables from vending market at Kalaburagi (Karnataka, India).

\section{MATERIALS AND METHODS \\ Sample collection}

A total 940 mixed fruits and vegetable were collected irrespective of verity from different super market in Kalaburagi, Kanni markets and Timmapuri (Karnataka) during October 2013- November 2015.Among the 940 samples, 390 were belongs to fruits and 550 were belongs to vegetables. The fruits and vegetables samples were collected in sterile polythene bags and transported to the laboratory within 2 hours of collection under aseptic conditions.

\section{Bacterial isolation and characterization}

From each collected vegetable and fruit sample, $0.5 \mathrm{~g}$ was aseptically weighed and $5 \mathrm{ml}$ of peptone water was added and keep it for 6hours in incubator shaker at $37^{\circ} \mathrm{C}$. After 6 hour, samples were enriched and then streaked on specific media like XLD, MacConkey and EMBagar the isolates were further identified on the basis of cultural, morphological and biochemical tests (Whitman, 2015, Mallikarjun and Gundappa 2016). The dehydrated readymade media were obtained from Himedia Limited, Mumbai India. The various morphological characteristics of isolates viz., colony morphological (Colour, Shape,Arrangement and Gram staining) were observed and analysed. The various biochemical tests like Indole test, Methyl Red, VogesProskauer test, Citrate Utilization test and triple sugar iron 
test (TSI) were done, for identification of isolates as per the procedure described earlier (Poonam, 2013).

\section{Antibiotic susceptibility testing}

The antibiotic susceptibility of the isolated E.coli, Salmonella and Shigella against the antimicrobials was determined by Kirby-Bauer disc diffusion method in Mueller-Hinton agar (Bauer et al., 1996). The inoculums were prepared at a density adjusted to a 0.5 McFarland turbidity standard solution.Three to five well isolated colonies of isolated bacteriawere transferred into $5 \mathrm{~mL}$ Brain Heart Infusion broth (BHIB, Oxoid) and incubated at $37^{\circ} \mathrm{C}$ for 18 to $24 \mathrm{hr}$. The overnight broth culture was diluted using sterile distilled water to a turbidity equivalent to $0.5 \mathrm{McF}$ arland standard (approximately $10^{8} \mathrm{cfu} / \mathrm{ml}$ ) and inoculated onto the entire surface of a dried Mueller-Hinton Agar (MHA, Oxoid) plate creating a lawn of the culture. The inoculated Muller Hinton Agar plates were allowed to dry at room temperature before placing the antibiotic discs followed by incubation. After incubation for 24 hours at $37^{\circ} \mathrm{C}$, the diameter (in $\mathrm{mm}$ ) of the zone around each disk was measured and interpreted in accordance with the Clinical and Laboratory Standards guidelines as described previously (CLSI, 2011).

The antibiotic resistant of bacterial isolates were assessed against the following antiboitucs, Ampicillin $(10 \mu \mathrm{g})$, Gentamicin $(10 \mu \mathrm{g})$, Ceftriaxone $(30 \mu \mathrm{g})$, Ciprofloxacin $(5 \mu \mathrm{g})$, Norfloxacin $(30 \mu \mathrm{g})$, Imipenem $(30 \mu \mathrm{g})$, Vancomycin $(30 \mu \mathrm{g})$, Trimethoprim-Sulfamethoxazole $(25 \mu \mathrm{g})$, Piperacillin $(10 \mu \mathrm{g})$, Amoxicillin $(10 \mu \mathrm{g})$, Chloramphenicol $(10 \mu \mathrm{g})$, Nalidixic acid

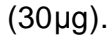

\section{Minimum inhibition concentration (MIC) assay}

Minimum concentration of each antibiotic inhibitory to the growth of 50 per cent $\left(\mathrm{MIC}_{50}\right)$ and 90 per cent $\left(\mathrm{MIC}_{90}\right)$ of each isolates were determined on MHA in a $90 \mathrm{~mm}$ plate. The agar contained concentration ranges of the antibiotics prepared by two-fold serial dilution according to the National Committee for Clinical Laboratory Standards (NCCLS, 1999).

\section{RESULTS AND DISCUSSION}

A total 940 samples (both fruits and vegetables) were collected from supermarket in and aroundKalaburagi (Karnataka, India) of which 390 were (23.84\%) fruits of different verities and 550 (35.27\%) were mixture of different types of vegetables. Among 390 fruitsand 550 vegetable samples, $93(23.84 \%)$ and 194 (35.27\%) were showed cultural positivity for the pathogenic bacteria respectively (Table 1). The number of isolated microbial colonies from different fruits and vegetables were represented in (Table 1) and (Fig 1 and 2).

Further, out of 93 positive samples, it is identified that $36.56 \%$ (34 out of 93) of Salmonella spp., $7.53 \%$ (7 out of 93) of Shigella spp. and 55.91\% (52 out of 93) of E. coli were isolated from fruit samples. Similarly, $35.60 \%$ of Salmonella spp., $25.26 \%$ of Shigella spp. and $38.14 \%$ E. coli was isolated from vegetable samples (Table 1). This clearly indicates that high level of pathogenic bacteria contamination found in food samples.Among the three pathogenic bacteria, the $E$. coli was found to be more prevalent $(13.49 \%)$ when compared to that of Salmonella(11.24\%) and Shigella (5.99\%)in the present study.

The antibiotic sensitivity for the three bacterial isolates was assessed using different antibiotics. High resistance for E. coli spp. Salmonella spp. and Shigella spp. to nalidixic acid $(86.50 \%)$, ciprofloxacin $(86.66 \%)$ and vancomycin $(80.35 \%)$ was observed respectively . However, respond $E$. coli, Salmonella and Shigella spp., showed a resistance to

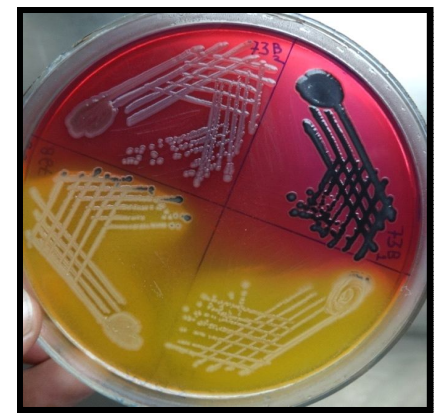

Fig 1: Plate showing the Bacterial isolates (A, E.coli, B, SalmonellaandC, Shigellaspp., on XLD agar media).

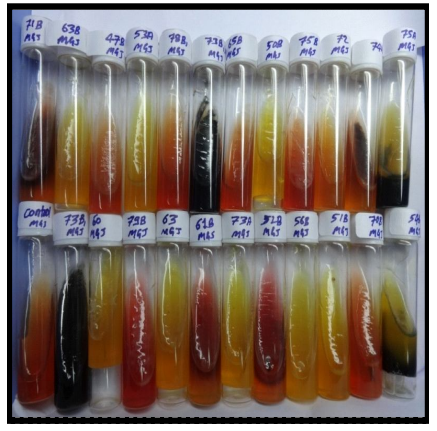

Fig 2: Plate showing the differential Biochemical test (Triple Sugar Iron test) for Bacterial isolates (E.coli, Salmonella and Shigellaspp.,)

Table 1: Pathogenic bacteria isolates from fruits and vegetables.

\begin{tabular}{|c|c|c|c|c|c|c|}
\hline \multirow{2}{*}{ Samples } & \multirow{2}{*}{$\begin{array}{l}\text { Samples } \\
\text { collected }\end{array}$} & \multirow{2}{*}{$\begin{array}{l}\text { Bacterial isolates } \\
\qquad(+ \text { culture })\end{array}$} & \multicolumn{4}{|c|}{ Number of positive samples } \\
\hline & & & Salmonella spp. & Shigella spp. & E. coli spp. & Total \\
\hline Fruits & 390 & 93 & $34 / 93(36.55 \%)$ & $7 / 93(7.52 \%)$ & $52 / 93(55.91 \%)$ & $93 / 390(23.84 \%)$ \\
\hline Vegetables & 550 & 194 & $71 / 550(36.59 \%)$ & $49 / 550(25.25 \%)$ & $74 / 550(38.14 \%)$ & $194 / 550(35.27 \%)$ \\
\hline Total & 940 & 287 & $105 / 940(36.58 \%)$ & $56 / 940(19.51 \%)$ & $126 / 940(43.90 \%)$ & $287 / 940(30.53 \%)$ \\
\hline
\end{tabular}




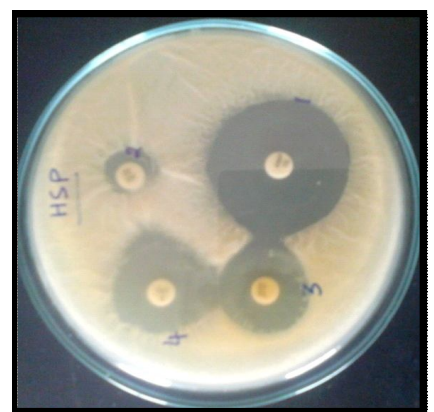

Fig 3a: Antibiotic Sensitivity Pattern of Bacterial isolates.

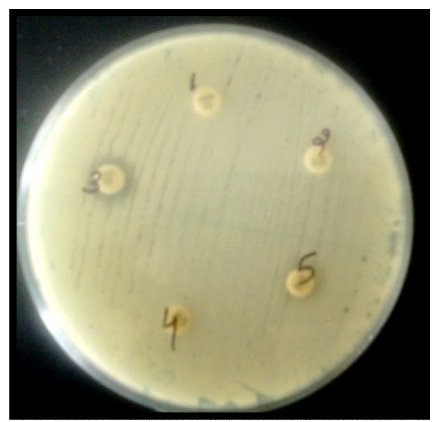

Fig 3b: Antibiotic Resistance Pattern of Bacterial isolates.

different antibiotics at different percentage level (Table 2, 3) and( Fig $3 a$ and b).

We further evaluated the MIC valuesfor E. coli, Salmonella and Shigella isolates. Among the three isolates, E.coli has shown highestMIC value to gentamicin $(4-16 \mu \mathrm{g} /$ $\mathrm{ml}$ ). Astonishingly, Salmonella has the higher MIC value toceftriaxone $(8-64 \mu \mathrm{g} / \mathrm{ml})$ andimipenem, $(4-16 \mu \mathrm{g} / \mathrm{ml})$. Similarly, Shigella isolates were shownhighest toampicillin $(8-32 \mu \mathrm{g} / \mathrm{ml})$ and nalidixic acid (13-32 $\mu \mathrm{g} / \mathrm{ml})$, when compare to that of other antibiotics (Table 4).

This study provides clear evidence of contamination of fresh Fruits and vegetables from common food-borne pathogens including E.coli, Salmonella and Shigella spp are important food-borne pathogen and its prevalence in fresh food poses a threat to human. The increase in demand and consumption of fruits and vegetables has resulted in a rise in food-borne related illnesses and outbreaks. Fresh fruits and vegetable have been reported to anchor potential foodborne pathogens including E.coli, Salmonella and Shigella spp., (Mallikarjun and Gundappa, 2016; Harris et al., 2003; CDC, 2009). E. coli has showed (54.55\%) to Nalidixic acid, similar Ampicillin and gentamicin (36.36\%,) Amoxicillin and ciprofloxacin were only (9.09\%) [29], Salmonella Showed $(42 \%)$ to Ampicillin and Shigella (79\%) (Biniam and Mogessie, 2010). The previous study was conducted on microbiological contamination in the Dhaka metropolis Bangladesh mainly forE.coli. it was observed that the \% of ABR for trimethoprim-sulfamethoxazole combination as $(46.03 \%)$ compared to the past results of \% ABR for same combination on E.coli. Similarly, it was found a steep decline in \% of ABR for amoxicillin from (46.2\%) (past research) to $(35.71 \%)$ (as per our results) similarly, indicating rise in microbial resistance to this antibiotic. However, there is a 
Table 3: Multiple drug resistance of E.coli, Salmonella and Shigella isolates isolated from fruits and vegetables.

\begin{tabular}{|c|c|}
\hline Number of resistant $E$. coli isolates $(n=49)$ & Drugs resisted \\
\hline 7 & AMP/CEF/IPM \\
\hline 3 & AMP/ NB/VAN/ AMO/ \\
\hline 9 & AMP/GEN/CEF/NALI \\
\hline 4 & AMP/CEF/NB/TMP-SLU/AMO \\
\hline 6 & AMP/CIP/NB/VAN/PIP/NALI \\
\hline 8 & IPM/VAN/TMP-SLU/PIP/CHL/NALI \\
\hline 12 & AMP/GEN/CEF/CIP/VAN/PIP/CHL \\
\hline Number of resistant Salmonella isolates $(n=28)$ & Drugs resisted \\
\hline 8 & AMP/CIP/ AMO \\
\hline 1 & CIP/ NB/TMP-SLU \\
\hline 4 & GEN/CIP/IPM/CHL \\
\hline 2 & GEN/CIP/CHL/NALI \\
\hline 6 & AMP/GEN/CIP/PIP /NALI \\
\hline 7 & AMP/CEF/CIP/IPM/VAN/CHL \\
\hline Number of resistant Shigella isolates $(n=6)$ & Drugs resisted \\
\hline 1 & CIP/VAN/NALI \\
\hline 1 & AMP/CEF/VAN \\
\hline 1 & AMP/VAN/NALI \\
\hline 1 & AMP/NB/ IPM/VAN \\
\hline 2 & AMP/ GEN/CIP/ NB/VAN/NALI \\
\hline
\end{tabular}

Multiple drug resistance (MDR) was seen in E. coli 49 (38.88\%), Salmonella 28 (26.66\%)andShigella 6 (10.71\%), isolates respectively.

Table 4: Minimum inhibitory concentrations (MICs) of antimicrobial agents for E.coli, Salmonella and Shigellaspp.

\begin{tabular}{|c|c|c|c|c|c|c|c|c|c|}
\hline \multirow{2}{*}{$\begin{array}{l}\text { Antimicrobial } \\
\text { drugs }\end{array}$} & \multicolumn{3}{|c|}{ E.coli } & \multicolumn{3}{|c|}{ Salmonella } & \multicolumn{3}{|c|}{ Shigella } \\
\hline & $\begin{array}{l}\text { Range } \\
(\mu \mathrm{g} / \mathrm{ml})\end{array}$ & $\begin{array}{c}\mathrm{MIC}_{50} \\
(\mu \mathrm{g} / \mathrm{ml})\end{array}$ & $\begin{array}{c}\mathrm{MIC}_{90} \\
(\mu \mathrm{g} / \mathrm{ml})\end{array}$ & $\begin{array}{l}\text { Range } \\
(\mu \mathrm{g} / \mathrm{ml})\end{array}$ & $\begin{array}{c}\mathrm{MIC}_{50} \\
(\mu \mathrm{g} / \mathrm{ml})\end{array}$ & $\begin{array}{c}\mathrm{MIC}_{90} \\
(\mu \mathrm{g} / \mathrm{ml})\end{array}$ & $\begin{array}{l}\text { Range } \\
(\mu \mathrm{g} / \mathrm{ml})\end{array}$ & $\begin{array}{c}\mathrm{MIC}_{50} \\
(\mu \mathrm{g} / \mathrm{ml})\end{array}$ & $\begin{array}{l}\mathrm{MIC}_{90} \\
(\mu \mathrm{g} / \mathrm{ml})\end{array}$ \\
\hline Ampicillin & $8-32$ & 16 & 32 & $8-32$ & 16 & 32 & $8-32$ & 16 & 64 \\
\hline Gentamicin & $4-16$ & 8 & 64 & $4-16$ & 8 & 32 & $4-16$ & 8 & 32 \\
\hline Ceftriaxone & $8-16$ & 16 & 32 & $8-64$ & 16 & 64 & $8-64$ & 16 & 32 \\
\hline Ciprofloxacin & $1-2$ & 2 & 4 & $1-4$ & 3 & 9 & $1-4$ & 4 & 8 \\
\hline Norfloxacin & $4-8$ & 8 & 16 & $8-16$ & 16 & 32 & $8-16$ & 5 & 8 \\
\hline Imipenem & $1-4$ & 2 & 4 & $4-16$ & 16 & 64 & $4-16$ & 8 & 16 \\
\hline Vancomycin & $4-32$ & 8 & 16 & $2-16$ & 4 & 8 & $2-16$ & 4 & 16 \\
\hline Trimethoprim- & & & & $2 / 38$ & & & $2 / 38$ & & \\
\hline Sulfamethoxazole & $2 / 38$ & $4 / 76$ & $8 / 156$ & $-4 / 76$ & $4 / 76$ & $8 / 152$ & $-4 / 76$ & $4 / 76$ & $8 / 152$ \\
\hline Piperacillin & $4-16$ & 8 & 16 & $4-16$ & 16 & 21 & $8-16$ & 16 & 32 \\
\hline Amoxycillin & $4-8$ & $8 / 16$ & 32 & $13-32$ & 16 & 32 & $16-32$ & - & - \\
\hline Chloramphenicol & $2-8$ & 4 & 8 & $8-16$ & 16 & 32 & $8-16$ & 6 & 8 \\
\hline Nalidixic acid & 8-32 & 16 & 32 & $13-32$ & 8 & 16 & $13-32$ & 16 & 64 \\
\hline
\end{tabular}

'steep rise' in \% of ABR for antibiotics such as impenem (from $0 \%$ to $19.84 \%$ ), gentamicin (from $0 \%$ to $32.53 \%$ ) and ceftriaxone (from $0 \%$ to $69.04 \%$ ) confirmed by these results. Therefore, our results indicating that the microbe i.e. E coli have acquired 'less antibiotic resistance to the above series of antibiotics' (Khatib et al., 2015).

A number of surveys have attempted to detect $E$. coli O157:H7 in fresh fruits and vegetables, in a study that included 3,200 vegetables, no $\mathrm{O} 157: \mathrm{H} 7$ positive sample was detected and in another survey of 890 fruits and vegetables, this pathogen could not be found either (Johannessen et al.,
2000). Salmonella resistance against ampicillin (55.5\%$31.4 \%)$, gentamicin (0\%-\%), ciprofloxacin $(6.5 \%-13.7 \%)$, vancomycin (100\%-100\%), trimethoprim-sulfamethoxazole (51\%-51\%), chloramphenicol (3.2\%-0\%) and nalidixic acid (0\%-5.9\%), against isolates from cabbage and spinach respectively (Isoken, 2015). Salmonellaspp., showed resistance against ampicillin $(100 \%)$, gentamicin $(0 \%)$, ciprofloxacin $(50 \%)$, trimethoprim-sulfamethoxazole $(6.3 \%)$, Amoxycillin (81.3\%), chloramphenicol $(6.3 \%)$ and nalidixic acid (12.5\%) (Najwa et al., 2015). E.coli, Salmonella and Shigella spp., showed resistance against, gentamicin $(60 \%)$, 
ciprofloxacin $(0 \%)$, Norfloxacin (10\%), amoxicillin $(70 \%)$, chloramphenicol (30\%), Salmonella gentamicin (7.7\%), ciprofloxacin $(0 \%)$, Norfloxacin $(0 \%)$, amoxicillin $(77 \%)$, chloramphenicol (92.3\%) and Shigella showed resistance against gentamicin $(0 \%)$, ciprofloxacin $(0 \%)$, Norfloxacin $(0 \%)$, amoxicillin (30\%), chloramphenicol (0\%), (Poonam, 2013). E.coli, Salmonella and Shigella spp., showed resistance against ampicillin $(25 \%)$, ceftriaxone $(67 \%)$, ciprofloxacin $(60 \%)$, trimethoprim-sulfamethoxazole $(20 \%)$, piperacillin $(30 \%)$, amoxicillin $(33 \%)$, chloramphenicol $(45 \%)$, nalidixic acid $(85 \%)$, Salmonella ampicillin (100\%), gentamicin $(0 \%)$, ceftriaxone $(0 \%)$, ciprofloxacin $(100 \%)$, trimethoprimsulfamethoxazole $(0 \%)$, amoxicillin $(0 \%)$, chloramphenicol $(0 \%)$, nalidixic acid $(0 \%)$, Shigella ampicillin $(100 \%)$, gentamicin $(0 \%)$, ceftriaxone $(0 \%)$, ciprofloxacin $(0 \%)$, vancomycin $(100 \%)$, trimethoprim-sulfamethoxazole $(0 \%)$,amoxicillin $(0 \%)$, chloramphenicol $(100 \%)$, nalidixic acid (100\%), (Nour et al., 2013). E. coli has been used as the reference indicator for faecal contamination and a number of surveys have reported its isolation from fresh fruits and vegetables (Jay, 2000). However, in the present study E. coli was found in $(26.8 \%)$ of conventional fresh vegetables in Lebanon, this result is consistent with the prevalence of $(25 \%)$ this bacterium in ready-to-use lettuce (Soriano et al., 2000).

The previous microbiological studies have illustrated to evaluate microbiological safety in various regions of Vidarbha through various 'antibiotic-microbial assays'. In the present study, it is been analyzed and compared antibiotic resistance (ABR) property in microbes such as ' $E$.coli, Salmonella and Shigella' using several antibiotics. It was found that the antibiotic resistance of E.coli to norfloxacin is almost $(36.5 \%)$ when compared to the past studies performed by others for studying same antibiotic resistance using same norfloxacin, where it was observed that only $(10 \%)$ of antibiotic resistance in $E$ coli. Similarly, previous reportshave got high antibiotic resistance for amoxicillin (70\%)but it was observed the 'antibiotic resistance for same amoxicillin' lesser \% of resistance $(35.71 \%)$. Similarly, the other researchers have observed antibiotic resistance using gentamicin $(60 \%)$ but we found lesser \% of resistance $(32.53 \%)$, where it was observeda huge variation in this antibiotic-resistance property for gentamicin. However, it was nearly $\mathrm{ABR}$ for chloromphenicol is $(23.80 \%)$ that slightly lesser than other researcher's result for $A B R$, where other reportsgot $(30 \%)$ whereas in present studyABR value $(53.93 \%)$ forciprofloxacin compared to the past research results for same antibiotic, where ABR value was $(0 \%)$. Here, it was clearly observedmore ABR for ciprofloxacin compared to the past results (Soriano et al., 2000).

It was observed ABR for norfloxacin on Shigella spp., approx. (26.78\%) compared tothe past results by other researchers where it was observed only $0 \%$ of $A B R$ on same species for same antibiotic. Similarly, we have observed lesser percentageof ABR for amoxicillin approx. (3.57\%) when compared tothe past researcher's result of $A B R$, which is nearly $(70 \%)$ on same Shigella species. There is a huge variation in $A B R$ results that could be due to the microbial ability to acquire resistance to amoxicillin antibiotic.It was found that the percentage of $A B R$ for gentamicin increased from $0 \%$ (as per past research) to (3.57\%) (as per our results) whereas the percentage of $A B R$ is nearly same and unchanged ( $0 \%$ for both past and our present work) for chromamphenicol on same Shigella species. However, there is a 'steep rise' in percentage of ABR for ciprofloxacin from percentage (as per past research) to (17.85\%) (as per results) (Soriano et al., 2000).

We have significantly observed that the percentage of ABR for norfloxacin on Salmonella spp. steeply 'reduced' from $30.8 \%$ (past research) to $(4.76 \%$ ) (as per our results) whereas the percentage of ABR for ciprofloxacin steeply 'increased' from percentage (past research) to (44.76\%) as per our results. Similarly, it is clearly observed with our results that the \% of $A B R$ for amoxicillin is $(3.80 \%)$, where past researchers have got $(69.2 \%)$ indicating 'high microbial resistance' to this antibiotic. In the meanwhile, the percentage of $A B R$ results for gentamicin is (9.52\%) whereas the past research has illustrated that the percentage ABR for same antibiotic is (84.6\%). It was observed that percentage ABR for chloromphenicol on Salmonella spp. (79.40\%) indicating a steep decline in ABR compared to the past results $(92.3 \%)$. Therefore, the microbial resistance patterns for this species on these antibiotics are quiet variable (Soriano et al., 2000; Poonam, 2013).

The present study provided valuable information regarding pathogenic bacteria species such as, E. coli, Salmonella and Shigella contamination of fruits or vegetables collected from various markets in Kalaburagi region. This data can facilitate the effective assessment of risk of contamination by E. coli, Salmonella and Shigella spp., in consumable nonprocessed fruits or vegetables in Kalaburagiregion suggesting potential public health hazard.

\section{CONCLUSION}

Antibiotic resistance patterns among the three major Enterobacteriaceae pathogens such as, E. coli, Salmonella spp. and Shigella spp., isolates from fruits, vegetable samples in Kalaburagi region has been evaluated and analyzed. Multi drug resistance (MDR) status has been found to be more prevalent predominantly among $E$. coli isolates than the other two pathogens thus calls for monitoring hygienic conditions in growing, processing and marketing of the consumable fruits and vegetables to prevent the risks of human health.

\section{Conflict of interest statement}

We declare that no conflict of interest.

\section{Authors contribution}

First author is responsible for carrying out the research work, data analysis and optimization of experimental work and Corresponding author is responsible for research planning executing and providing valuable inputs and in writing manuscript. 


\section{REFERENCES}

Akinyele, B.J and Akinkunmi, C.O. (2012). Fungi associated with the spoilage of berry and their reaction to magnetic field. Journal of Yeast and Fungal Research. 3(4): 49-57.

Bauer, A.W., Kirby M., Sherris, J.C. and Turck, M. (1966). The American Journal of Clinical Pathology. copyright@1966 by the Williams and Wilkins Co. 45(4).

Beuchat, L.R. (1995). Pathogenic microorganisms associated with fresh produce. Journal of Food Protection. 59: 204216.

Biniam, G., Mogessie, A. (2010). Microbial load prevalence and antibiogram of Salmonella and Shigella in lettuce and green peppers. Ethiopian Journal of Health Sciences. 20: 4148.

Bryan, F.L, Jermini M, Schmitt R, Chilufya EN, Mwanza M, Matoba A, Mfume E, Chibiya $H$. (1997). Hazards associated with holding and reheating foods at vending sites in a small town in Zambia. Journal of Food Protection. 60: 391-398.

Buck, J.W, Walcott R.R, Beuchat L.R. (2003). Recent trends in microbiological safety of fruits and vegetables. Plant Health Progress. 10: 1094.

Cappuccino, J.G., Sherman, N. (2005). Microbiology: A Laboratory Manual. New Yark. pp. 125-79.

CDC. (2009). Surveillance for food-borne disease outbreaks-United States, Centers for Disease Control and Prevention. Morb Mortal Weekly Report. 58: 609-15.

CLSI. (2011). Clinical and Laboratory Standard Institute Standards Guidelines.

Dahiru, M., Enabulele, O.I., Musa, J., Sharfadi, R.S., Ibrahim, A., Yahaya, H. (2015). Antibiogram of pre-harvest Escherichia coli 0157:H7 on cabbage irrigated with wastewater, International Journal of Public Health Research. 3(1): 4448.

Davis, M.A., Hancock, D.D., Besser, T.E, Rice, D.H., Gay, J.M., Gay, C., Gearhart, L., Difiacomo, R. (1999). Changes in antimicrobial resistance among Salmonella enterica serovar. Infectious Diseases. 5: 802-806.

De Rover, C. (1998). Microbial Safety Evaluations and Recommendation on Fresh Produce. Food Control. 9(6): 321-347.

Fain, A.R. (1996). A review of the microbiological safety of fresh salads. Dairy Food Environmental Sanitation Journal. 16: 146-149.

Hamilton, A.J, Stagnitti F, Premier R., Boland, A.M., Hale G. (2006). Quantitative microbial risk assessment models for consumption of raw vegetables irrigated with reclaimed water. Applied and Environmental Microbiology. 72: 3284-3290.

Harris, L.J., Farber J.N., Beuchat, L.R., Parish, M.E., Suslow, T.V., Garrett, E.H. and Busta, F.F. (2003). Outbreaks associated with fresh produce: Incidence, growth and survival of pathogens in fresh and fresh cut produce. Comprehensive Reviews in Food Science and Food Safety. 2: 78-141.

Hedberg, C.W., MacDonald, K.L., Osterholm, M.T., (1994). Changing epidemiology of food-borne diseases: A Minnesota perspective. Clin. Infect. Dis. 18: 67-682.

Isoken, H. (2015). Igbinosa Biofilm formation of Salmonella species isolated from fresh cabbage and spinach. Journal of Applied Science and Environmental Management. March, Environmental Man.
Jay, J. (2000). Modern food microbiology, $6^{\text {th }}$. ed. Aspen Publishers, Gaithersburg.

Johannessen, G., Loncarevic, S. and Kruse, H. (2000). Bacteriological analysis of fresh produce in Norway. International Journal of Food Microbiology. 77: 199-204.

Khatib, A. Olama Z and Khawaja G.1. (2015). Shiga Toxin-Producing E. coli (STEC) Associated with Lebanese Fresh Produce, International Journal of current Microbiology and Applied Sciences. 4(2): 481-496.

Kilonzo, N.A., Rotich, E. and Thompson, C. (2009). Antibioticresistant bacteria isolated from organic and conventional fresh produce. National Institute of Food Technology.

Kumar, K., Gupta, S.C., Baidoo, S.K., Chander, Y and Rosen, C.J. (2005). Antibiotic uptake by plants from soil fertilized with animal manure. Journal of Environmental Quality. 34: 2082-2085.

Liu, R.H. (2003). Health benefits of fruit and vegetables are from additive and synergistic combinations of phytochemicals American Journal of Clinical Nutrition. 78(3): 517-520.

Mahima, Verma, A.K., Tiwari, R., Karthik, K., Chakraborty, S., Deb, R. and Dhama, K. (2013). Nutraceuticals from fruits and vegetables at a glance: A review. Journal of Biological Sciences. 13(2): 38-47.

Mallikarjun Gundappa and Gaddad, M. (2016). Prevalence of Enteric Pathogens In The Fruits of Super Markets In Kalaburagi Region, Karnataka, India. International Journal of Agriculture and Food Science. 6(1): 1-5.

Mallikarjun Gundappa and Gaddad, M. (2016). Prevalence of Salmonella, Shigella and E. coli in vegetables of various markets in Kalaburagi (India). Indian Journal of Natural Sciences. 6(35): ISSN: 0976-0997.

Martin, D.L., Mead, P.S, Suarez, L., Shuster, L. (2003). Food related illness and death in the United States. Emerging Infectious Diseases. 5: 607-625.

Najwa, M.S., Rukayadi, Y., Ubong, A., Loo, Y.Y., Chang, W.S., Lye, YL et al. (2015). Quantification and antibiotic susceptibility of Salmonella spp., Salmonella Enteritidis and Salmonella Typhimurium in raw vegetables (ulam), International Food Research Journal. 22(5): 1761-1769.

National Committee of Clinical Laboratory Standards. Performance standards for antimicrobial susceptibility testing: eighth international supplement. (1999). Wayne, PA: National Committee for Clinical Laboratory Standards, (NCCLS document no. M100-S8).

Nour, F., Mrityunjoy, A., Rashed, N., (2013). Microbiological Profiling of Imported Apples and Demonstration of Bacterial Survival Capacity through in vitro Challenge Test American. Journal of Microbiological Research. 1(4): 98-104.

National Committee of Clinical Laboratory Standards. Performance standards for antimicrobial susceptibility testing: eighth international supplement. (1999). Wayne, PA: National Committee for Clinical Laboratory Standards, (NCCLS document no. M100-S8).

Pandey, K.B. and Rizvi, S.I. (2009). Plant polyphenols as dietary antioxidants in human health and disease. Oxidative Medicine and Cellular Longevity. 2: 270-8.

Poonam, U. Sharma, (2013). Bacteriological analysis of street vended fruit juices available in Vidarbha. International Journal of Current Microbiology and Applied Sciences. 2(5): 178-183 ISSN: 2319-7706. 2(5): 178-183. 
Ray, B and Bhunia, A.K. (2007). Fundamental Food Microbiology. $4^{\text {th }}$ edn. CRC Press, USA. 492.

Robinson, R.K, Batt, C.K, Patel, C.D, (2000). Raw fruits and vegetables as sources foodborne diseases. Encyclopedia of food microbiology, Academic Press, San Diego. Pp. 706788.

Soriano, J., Rico, M., Molto, J. (2000). Assessment of the microbiological quality and wash treatments of lettuce served in University restaurants. International Journal of Food Microbiology. 58: $123-128$.
Tauxe, R., Kruse, H., Hedberg, C., Potter, M., Madden, J., Wachsmuth, K. (1997). Microbial hazards and emerging issues associated with produce. A preliminary report to the national advisory committee on microbiological criteria for foods. Journal of Food Protection. 60: 1400-1408.

Whitman, W.B. (2015). Bergey's manual of systematic of Archaea and Bacteria. New York: Wiley.

World Health Organization (WHO). (2008). Microbiological hazards in fresh fruits and vegetables. Microbiological risk assessment series. 